\title{
Liquidation and merger conditions in the banking industry: the Itaú-Unibanco case ${ }^{*}$
}

\author{
Monique de Abreu Azevedo ${ }^{1}$ \\ (D) https://orcid.org/0000-0003-4897-7227 \\ Email: monique.azevedo@bcb.gov.br \\ Ivan Ricardo Gartner ${ }^{1}$ \\ (D) https://orcid.org/0000-0002-9780-1212 \\ Email: irgartner@unb.br
}

${ }^{1}$ Universidade de Brasília, Faculdade de Economia, Administração, Contabilidade e Gestão de Políticas Públicas, Programa de Pós-Graduação em Administração, Brasília, DF, Brazil

Received on 05.10.2018 - Desk acceptance on 07.23.2018 - $3^{\text {rd }}$ version approved on 01.29.2019 - Ahead of print on 05.30.2019

Associate Editor: Fernanda Finotti Cordeiro Perobelli

\begin{abstract}
This study's main objective is to present the circumstances that signal an imminent commercial bank liquidation and the conditions in which mergers are advantageous for a potential acquirer. In addition, it applies the method in an empirical investigation within the context of the domestic banking industry. The research reveals new explanatory factors for liquidations and mergers between robust and insolvent banking institutions, such as bankruptcy costs and tax credits derived from a corporate union. The framework stands out for highlighting the role of creditor financial institutions participating in the open and interbank markets, which in the search to maximize their utility together with that of the shareholders have a decisive influence over the continuity or closure of the bank in crisis. The soundness of the financial system is an essential public good for society. Systemic financial crises cause significant costs for economic agents, such as a fall in production, increased unemployment, a rise in the fiscal deficit, and asset price instability. Efforts to achieve stability involve the regular functioning of banks. In this context, it is important to understand the circumstances under which banking institution distress can be solved by alternatives that are less costly for the treasury. Often, the research indicates the causes of disruptions to corporate activities; however, the explanatory variables and the tools used by bankruptcy prediction models are constantly being evaluated. Theories that elucidate the phenomenon are even scarcer. The paper's result suggests the effectiveness of the method developed from the paradigmatic perspective of the field of economics and management, corroborating agency theory. The explanatory variables of bankruptcy and bank merger highlighted in this research can contribute to the elaboration of robust models to predict financial distress. The mathematical model of liquidation and merger was constructed from the viewpoint of an imperfect world where informational asymmetry and conflict of interests among shareholders, open and interbank market creditors, and bondholders (which includes depositors and holders of bonds issued by the bank) prevail. Bankruptcy maximizes shareholder and creditor utility if liquidation costs plus the value payable to the bondholders after liquidation are lower than the value they receive in the event of continuity. A merger is feasible for an acquirer if expected return plus tax benefits minus bondholder expenses is greater than the value payable to interbank market creditors. The method is applied to the merger between Itaú and Unibanco, considered a milestone in the process of consolidating the banking market in Brazil. This paper suggests the use of an algebraic model, based on agency theory, as an indicator of conditions for liquidations and bank mergers. The proposed approach was adequate for explaining the union between Unibanco and Itaú, which culminated in the largest private financial conglomerate in the Southern Hemisphere. Unibanco experienced the bankruptcy circumstances and there was evidence that Itaú's tax benefits encouraged the merger. This article contributes to academic epistemology because it revisits the classical model, characterized by mathematical and theoretical robustness, and adjusts it to the specificities of banks. In addition to this methodological novelty, it applies it to an emblematic case, making it a useful tool for corporate decision-making and bank supervision, especially with regards to actions focused on financial stability.
\end{abstract}

Keywords: information asymmetry, conflict of interests, liquidation, merger, banks.

Correspondence address

Monique de Abreu Azevedo

Banco Central do Brasil

Setor Bancário Sul, Quadra 3, Bloco B, $15^{\circ}$ andar - CEP 70074-900

Asa Sul - Brasília - DF - Brazil

*Article presented at the XLI ANPAD Conference, São Paulo, SP, Brazil, October of 2017. 


\section{INTRODUCTION}

The literature in the field of corporate finance highlights the trade-off between the tax benefits and risk of corporate default derived from financial leverage. Depending on the level and speed of indebtedness, insolvency costs tend to increase and, consequently, bankruptcy may become feasible. Indeed, the interest on third-party capital is tax deductible, while the dividends paid to shareholders do not enjoy this advantage. However, as an organization takes out loans, its risk of defaulting rises due to the new amortization and interest-payment obligations.

Despite the obstacles to measuring the expenses associated with bankruptcy, studies support their relevance to the firm's capital structure (Baxter, 1967; Kraus \& Litzenberger, 1973). Several studies also indicate their impacts on the strategies used in relation to the continuity or interruption of company activities (Bulow \& Shoven, 1978; White, 1983, 1989).

With regards to bank failure, there is the risk of default contagion and of the failure of at least one other financial institution (FI), via its multilateral financial exposures (Angelini, Maresca, \& Russo, 1996). Systemic risk, understood as the probability of cumulative losses occurring due to an event that gives rise to successive losses throughout a chain of institutions or connected markets (Kaufman, 1994), negatively affects economicfinancial stability.

The soundness of the financial system is one of the essential pure public goods for society. Efforts to achieve it involve the robustness, reliability, and regular functioning of banks. In this context, there is a need to understand the circumstances under which banks fail and to find feasible alternatives to collapse. Systemic financial crises imply significant costs for economic agents, such as a fall in production, increased unemployment, a rise in the fiscal deficit, and asset price instability (Alvarez-Jimenez, 2014; Babecky et al., 2013). The adverse systemic effects explain the interest of this research in detecting the factors that lead to imminent bank liquidations and the incentives for private restructuring.

For this, this study revisits the classical theoreticalmathematical model, based on the level of informational asymmetry and on the conflict of interest between parties that have rights over the firm's assets and income. The chosen framework, proposed by Bulow and Shoven (1978), stands out for analyzing bankruptcy and restructuring from the stakeholder-agency theoretical perspective (Donaldson \& Preston, 1995; Hill \& Jones, 1992).
Given the importance of understanding bank failure and private solutions to the crisis, the explanatory variables present in the original model from Bulow and Shoven (1978) are adjusted in order to incorporate the idiosyncrasies of multiple banks with a commercial portfolio. Complementarily, the paper analyzes the merger of Banco Itaú Holding Financeira S.A. (Itaú) with Unibanco Holding S.A. and União de Bancos Brasileiros S.A. (Unibanco), announced in 2008. The union, which culminated in the biggest private bank in the Southern Hemisphere (Itaú Unibanco Banco Múltiplo S.A., 2008), presents characteristics that adhere to the assumptions of the model from Bulow and Shoven (1978), namely: financial difficulties, indications of conflicts of interest within the acquired bank, as well as evidence that tax gains incentivized the merger.

On November $3^{\text {rd }}$ of 2008, when the controllers of Itaúsa - Investimentos Itaú S.A. and Unibanco Holdings S.A. announced the union (Itaúsa and Unibanco), the hypothesis emerged that Unibanco's financial deterioration had contributed to the merger. On October $24^{\text {th }}$ of 2008, in the midst of the international crisis, Unibanco and Itaú brought forward their falling results (Itaú Unibanco Banco Múltiplo S.A, 2008). Unibanco was pressured into communicating the mark-to-market of the derivative operations of its corporate clients, of R 1 billion (União de Bancos Brasileiros S.A. - Unibanco, 2008a). The currency hedge contracts, carried out due to investments abroad of $\mathrm{R} \$ 10.5$ billion, also required deposits of additional margins in the organized Stock Exchange market, which acts as a central counterparty.

Also, concerning the assumptions of the reference model (Bulow \& Shoven, 1978) and its similarities to the specific case, besides the financial difficulties, there were indications that Unibanco's shareholders sought to maximize their individual utilities. With the restructuring, its controllers, the brothers Fernando Roberto Moreira Salles (industrialist), Walther Salles (filmmaker), João Moreira Salles (documentary maker), and Pedro Moreira Salles (banker), received an expressive premium on their ordinary shares. The hypothesis that most of the Moreira Salles family members had no interest in the continuity of the business suggests greater adherence of the case studied to the theoretical-quantitative model developed in this article. Constructed to study the motives that lead a firm to bankruptcy or permanence in the market, the Bulow and Shoven (1978) framework proves, a priori, to 
be adequate for analyzing banks. Besides the technical robustness, it is consistent with the recommendations of the Financial Stability Board (FSB, 2014) with regards to private solutions, such as mergers and acquisitions (M\&A), that aim to restructure the businesses of a bank in crisis and attenuate the risk of contagion.

This paper adjusts the classical model to commercial banks - henceforth banks - and applies it to a representative case of the local financial industry, seeking a useful tool for academia, the agents involved in decision-making processes, and bank supervision. The next section presents the theoretical framework focusing on bank insolvency and merger. The subsequent section is dedicated to the method. Then, the model is applied to the Itaú-Unibanco case. Finally, the results analyses and conclusions are developed.

\section{THEORETICAL-EMPIRICAL FRAMEWORK}

Modigliani and Miller (1958) are the pioneers of modern finance with their publication of the study on the irrelevance of capital structure. In this classic paper, they concluded that, under certain assumptions, such as the absence of bankruptcy, agency, and informational asymmetry costs, a company's value does not depend on the form of financing adopted. Although they accept the possibility of bankruptcy given the inability to repay loans, they did not address bankruptcy costs directly. In 1963, by including tax costs and benefits in the analysis, Modigliani and Miller found that a company's value grows with leverage.

With the relaxing of the constraints of the inaugural study from 1958, different theories have emerged concerning corporate decisions. Trade-off theory, proposed by Kraus and Litzenberger (1973), warns that despite the tax advantage derived from financing through debt, the expenses associated with indebtedness tend to increase. Thus, a company will issue bonds while the tax benefit is equal to or greater than the costs generated by the leverage.

The studies on bankruptcy and restructuring emerge from the reflections regarding capital structure. The expenses related to the possibility of a company not fulfilling its obligations due to excess leveraging are known as direct and indirect bankruptcy costs. These expenses include legal and administrative costs, as well as higher interest rates imposed by creditors due to the increased risk of default and those associated with corporate restructuring (Frank \& Goyal, 2009; Rasiah \& Kim, 2011).

The uncertainties in estimating bankruptcy costs have not prevented the science on the theme from advancing. Altman (1984) demonstrated their empirical relevance for capital structure and that they can exceed $20 \%$ of firm value, measured before failure. He also identified the impact of macro and microeconomic factors, such as real economic growth, the stock market, credit supply, and competition in the bankruptcy sector. In 1993, Altman shed light on manager efficiency being a main cause of the phenomenon.

Bris, Welch, and Zhu (2006) showed that bankruptcy costs may not be modest and that liquidations are not cheaper than restructuring. Hiring professionals specialized in maximizing the value of the closed company makes the process more expensive. According to the authors, at the beginning of the bankruptcy process, insolvency costs varied between 2 and 20\% of assets. On average, the direct costs amounted to $80 \%$ of postbankruptcy assets and $9.4 \%$ in companies undergoing restructuring. The devaluation of the goods and rights of companies in a bankruptcy process and, especially, of those closed down, was expressive.

Since banks are different in terms of the role they play, the business model, and the underlying regulatory framework, they prompt specific studies concerning bankruptcy and restructuring. Bankruptcy costs should contemplate, for example, constraints imposed by the regulator for non-compliance with the minimum level of regulatory capital (Ayuso, Perez, \& Saurina, 2004). James (1991) estimated that bankruptcy costs represent 30 cents per dollar of assets in a liquidated bank. The experience of the Federal Deposit Insurance Corporation (FDIC) suggests that the administrative costs of bankruptcy amount to $7 \%$ of pre-liquidation assets (Hardy, 2013) and the losses in value of goods and rights add up to $18 \%$ (Bennett \& Unal, 2014; Mason, 2005).

Altman (1968) incentivized the use of statistical models to predict bankruptcy. Based on a multivariate discriminant analysis, known as Z-score, he constructed a linear combination of variables representative of liquidity, profitability, indebtedness, solvency, and efficiency capable of discriminating insolvent and solvent industrial companies with precise results for predicting bankruptcy, one year before the occurrence.

Logistic regression analysis goes beyond a dichotomous classification of banks. In logit, the probability of insolvency 
depends on economic-financial indicators on a date prior to failure and their coefficients. Zaghdoudi (2013) showed that the probability of a bank failing reduces with a greater ability to pay its debts and operating costs and with greater returns per employee and leverage. The proportional risk models predict the time for failure (Cox, 1972). Recently, the studies have used computational methods, such as genetic algorithms (Nanda \& Pendharkar, 2001), neural network algorithms (Ravi \& Pramodh, 2008), fuzzy logic algorithms (Yildiz \& Akkoc, 2010), and machine learning algorithms (Abu-Mostafa, Magdon-Ismail, \& Lin, 2012).

Based on the statistical models, supervisory bodies have constructed systems for monitoring FIs. In the United States, Camels classifies banks according to economicfinancial indicators representative of capital, asset quality, management, returns, liquidity, and sensitivity to market risk (Koch \& MacDonald, 2000). The Central Bank of Brazil (CB) has developed INDCON - EconomicFinancial Indicators of Institutions under Supervision and Control (Janot, 2001). With his 68 indicators applied to a logit model, Janot (2001) found insolvency of 18 of the 21 FIs in the sample of banks that underwent an intervention or were liquidated by the CB between 1995 and 1996. The proportional risk model found 20 events and correctly indicated the period in which they occurred, predicting 95\% of the insolvent banks six months in advance.

Company mergers represent an alternative to financial difficulties, as well as a way of achieving efficiency gains. Hankir, Rauch, and Umber (2011) present the motivations for bank M\&As: market power; waves of corporate restructuring incentivized by greater market concentration; preventative mergers, in which the buyer's desire to prevent its competitors from acquiring preferential targets prevails; operational and financial synergies derived from economies of scale and scope; and financial problems in which mergers are motivated by low financial performance of the target companies.

Bulow and Shoven (1978) treat mergers as an informal private alternative to bankruptcy for a firm in financial distress. The mathematical model developed detects how conflict of interests and different degrees of informational asymmetry between classes of claimants to a company affect the prospects for the organization's continuity. In reference to agency theory (Jensen \& Meckling, 1976), the method stands out, above all, for identifying that the owners and creditor banks of a firm hold the power over the business' continuity or closure.

When empirically investigating the incentives of firms in financial distress to restructure their debts privately, Gilson, John, and Lang (1990) highlighted that the conflict of interests between creditors of a firm undergoing a bankruptcy process has a complex outcome. Thus, private restructuring is less likely to occur when there are various different classes of creditors. Besides the higher negotiation cost, it is harder to reach a consensus. The solution for financial distress, whether through bankruptcy or private restructuring, depends on whether the shareholders and creditors will benefit, that is, if they will face lower costs than in the case of bankruptcy.

In addition, Bulow and Shoven (1978) evaluate the effect of the appropriation of the tax credits of a company in crisis by a potential acquirer, since this tax advantage cannot be enjoyed after bankruptcy. White $(1983,1989)$ broadened the framework by examining the choices of firms from the private viewpoint and, also, under the aegis of bankruptcy regulation. Fisher and Martel (2009) tested the model and their results support the theory. The probability of restructuring was raised with asset liquidity, firm size, and the reduction of debt. The higher the firm's liquidation value, the lower the chance of restructuring.

\section{ANALYSIS METHOD}

\subsection{Classes of Claimants in the Context of a Firm and a Commercial Bank}

The degree of information asymmetry and conflicts of interests between shareholders, lending banks, and bondholders regarding the assets and income of a firm in financial difficulties are central in the model established by Bulow and Shoven (1978). In this context, the actions taken in relation to the firm's bankruptcy or continuity are those that maximize the joint utility of the shareholders and the creditor banks of the company, independently of their effects on the bondholders.
Lending considerable short-term funds, the creditor banks group is formed of a few big FIs that seek to maintain a close relationship with the company. In Brazil, in December of 2017, four banks accounted for $78 \%$ of credit in the country (Banco Central do Brasil - BC, 2018). In December of 2007, before the global financial crisis and the merger analyzed in this article, this percentage was $54.7 \%$. In this period, the number of banks operating in Brazil decreased, via a process of M\&A of institutions most vulnerable to the crisis.

FIs have the same perception regarding the probabilistic distribution of a firm's productivity as that of shareholders, 
which facilitates the implementation of loans. Bulow and Shoven (1978) also argue that a firm prefers to resort to banks when faced with a lack of liquidity. The issuing of shares and bonds may not provide the necessary resources, as well as sometimes being costly when faced with financial difficulties.

The cohesive nature of the creditor bank class, strengthened by the concentration of this market, along with the informational asymmetry, increases its power and ability to negotiate the terms of its loans to shareholders. Moreover, the organization's dependence in relation to this source of capital favors the coalition between banks and owners with regard to the firm's strategies. FIs recognize their power to force bankruptcy or provide the resources needed to maintain the company afloat.

The bondholder class is formed of small individual investors, such as debenture and promissory note holders. It is therefore a fragmented, non-cohesive group that consequently has a low capacity for renegotiation of the terms of its bonds with the shareholders when bankruptcy becomes a possibility. In addition, the incomplete information regarding the real situation of the company reduces the influence of bondholders over the firm's bankruptcy or permanence.

In the context of a commercial bank, the claimant classes are also represented by shareholders, creditor banks, and bondholders, to which depositors are also added. Banks provide loans to other banks, via open market and interbank operations. The bondholders are holders of bonds issued by the FI. There is also a noteworthy dependence on deposits to raise funds, which are unstable and subject to bank runs (Diamond \& Rajan, 2000). Allen, Carletti, and Marquez (2015) also highlight the relevance of deposits.

In the open market, banks and the $\mathrm{CB}$ exchange liquidity via definitive or repo purchases and sales of federal government bonds. In the interbank market, the banks carry out operations with each other, using bonds issued by the banks themselves as collateral, the Interbank Deposit Certificate (IDC). The Brazilian banking market is formed of a few big FIs that dominate the sector (Banco do Brasil, Caixa Econômica Federal, Itaú-Unibanco, Bradesco, and Santander). This is a cohesive group with complete information in relation to the borrowing bank. Therefore, the class tends to have the ability to negotiate the terms of its transactions with shareholders.

As fundraising in the open market usually occurs via repo and reverse repo operations, non-payment of interest or of the principal on these transactions means the creditor FI keeps the bond. The low risk intrinsic to repos means members of the open money market are willing to provide funds to a bank in financial distress. This reinforces the assumption that shareholders preferentially resort to creditor banks when they are faced with insufficient cash flow.

Fundraising by Unibanco in the open and interbank market in the quarter prior to the merger (third quarter of 2008) represented $32.3 \%$ of its total liabilities (Unibanco, $2008 \mathrm{~b}$ ) and was the organization's second biggest source of funds. In the money market, FIs primarily raise funds in the short term, increasing their capacity to force bankruptcy, interrupting the provision of funds or support, by means of additional liquidity.

The bondholders group is represented by the holders of bonds issued by the bank, such as real estate, mortgage, and credit notes. The depositors group presents similar characteristics to bondholders, except interbank depositors, which form part of the creditor banks class. Both the bondholders and the depositors are formed of numerous, especially small-sized agents, forming a fragmented and non-cohesive class. In addition, due to informational asymmetry, they have a low ability to negotiate with shareholders and to influence the organization's prospects.

Fundraising from bondholders and depositors represented $34.4 \%$ of Unibanco's liabilities (Unibanco, $2008 \mathrm{~b}$ ) and was the biggest source of funds. Sheng (1990) considers depositors to be among the classes of claimants to a bank, besides shareholders (or managers) and bondholders. In this study, shareholders, creditor banks, depositors, and bondholders constitute the main classes of a bank.

\subsection{The Theoretical-Mathematical Model}

The reference model considers two periods without specifying the duration. This study considers that operations classified in current assets and liabilities on the Balance Sheet (BS) refer to $t_{1}$ and those recorded in realizable assets and long-term liabilities refer to $t_{2}$. According to the Accounting Plan of the Institutions of the National Financial System (Cosif) (CB, 1987), the values classified in current assets and liabilities are, respectively, realizable and due over the course of the 12 months following the BS, and those in realizable assets and long-term liabilities are realizable and due after those 12 months.

The algebraic condition of bankruptcy is established by inequation 1 . The expression suggests that liquidation maximizes the shareholders' and creditor FIs' utility if the bankruptcy costs plus the value payable to the bondholders in the event of the organization's closure is lower than the value payable to the bondholders in the event of continuity. 
In the case of banks, besides the bondholders, the values payable to the depositors should also be considered.

$$
B C+D_{b}<D_{c}
$$

$B C$ is the bankruptcy costs, $D_{b}$ is the value payable to the holders of bonds issued by the bank (bondholders) and to the depositors in the case of liquidation, and $D_{c}$ is the expected present value payable to the bondholders and depositors in the case of continuity.

Bulow and Shoven (1978) detect bankruptcy costs as the difference between the expected value of earnings and the liquidation value of the company's physical assets (equation 2). The proposed bank financial distress model detects bankruptcy costs in the same way. The expenses associated with bank liquidation are similar to those of a non-financial organization, and could be greater (Hardy, 2013) due to specific costs, such as those related to the non-repayment of loans (Belém \& Gartner, 2016).

$$
B C=P-L
$$

$P$ is the expected present value of the bank's future profits and $L$ is the liquidation value of the goods and rights (except liquid assets), minus obligations.

Inequation 1 requires an estimate of the expected value that the bondholders and depositors would receive in the event of liquidation $\left(D_{b}\right)$; as well as of the amount payable to these classes in the case of the bank's continuity $\left(D_{c}\right)$, as according to equations 3 and 4 .

$$
D_{b}=\left\{\begin{array}{l}
\frac{D_{1}+D_{2}}{D_{1}+D_{2}+B_{1}}(C+L), \text { if } 0 \leq C+L \leq\left(D_{1}+D_{2}+B_{1}\right)\left(1+r_{D}\right) \\
p_{1}+D_{2}+r_{1}, \text { if }\left(D_{1}+D_{2}+B_{1}\right)\left(1+r_{D}\right) \leq C+L
\end{array}\right.
$$

in which $D_{1}$ is the value of the principal of the deposits (except interbank deposits) and of the bonds issued by the bank maturing in $t_{1}$ [classified in current liabilities (CL) on the bank's BS]; $D_{2}$ is the value of the principal of the deposits (except interbank ones) and of the bonds maturing in $t_{2}$ that can be withdrawn/redeemed by the client/investor, represented by a fraction of the deposits and by the total bonds classified in long term liabilities (LTL); $B_{1}$ is the face value payable to the bank's creditor financial institutions, in $t_{1}$, represented by the funds raised in the open money and interbank market classified in $\mathrm{CL} ; C$ is the cash or liquid assets classified in the bank's current assets (CA), which includes compulsory ones in cash and bonds deposited in a bank reserve account at the $\mathrm{CB} ; r_{1}$ is the value of the interest applicable to the deposits (except on interbank deposits, contemplated in the value payable to the banks $B$ ) and to bonds issued by the bank, maturing in $t_{1}$, that is, classified in CL; and $r_{D}$ is the interest rate paid to the depositors and holders of bonds issued by the bank in $t_{2}$.

$$
D_{C}=r_{1}+D_{1}+\frac{D_{2}}{\left(D_{2}+B_{2}\right)(1+i)} \int_{0}^{\left(D_{2}+B_{2}\right)\left(1+r_{D}\right)} \Phi f(\Phi) d \Phi+\frac{D_{2}\left(1+r_{D}\right)}{1+i} \int_{\left(D_{2}+B_{2}\right)\left(1+r_{D}\right)}^{\infty} f(\Phi) d \Phi
$$

in which $B_{2}$ is the face value payable, in $t_{2}$ to the creditors of the bank participating in the open and interbank market due to the need for liquidity, classified in LTL; $i$ is the discount rate used by the open and interbank market participants; $(\Phi)$ is the cash generated by the bank's future results in $t_{2}$; and $f(\Phi)$ is the probability distribution of the cash generated by the bank's future results in $t_{2}$.

In Bulow and Shoven (1978), the non-receipt of interest or of the principal by the bondholders implies the company's default. Therefore, the holders of corporate bonds maturing in $t_{1}$ are paid independently of cash flow. In the event of a lack of funds, financial distress is configured in $t_{1}$ and the organization resorts to bank loans. In banks, impossibilities to withdraw deposits or redeem bonds can lead to a bank run. In fact, some of the deposits, such as cash and savings account ones, allow withdrawal at any time. Consequently, banks keep these resources $\left(D_{1}\right)$ accessible in $t_{1}$.

In $t_{2}$, the value payable to depositors and bondholders $\left(D_{2}\right)$, just as in the original model, depends on the liquidation value of the institution $(C+L)$ in the event of bankruptcy and on the probability distribution of cash flow $[\Phi f(\Phi)]$ in the case of continuity. In the event of bankruptcy, the amount raised with the sale of goods and rights, net of obligations $(L)$, and cash $(C)$, are distributed among the claimant classes. The values distributed depend on the rules for repayment to the classes. As this is an analysis of a bankruptcy situation before the formal liquidation process, it is assumed that the creditor banks, depositors, and bondholders have equal priority of receipt 
and the shareholders, the last ones to receive, do not pocket anything in the event of bankruptcy.

Therefore, if the liquidation value of the bank or of the profit is insufficient to pay the institutions participating in the money market, creditors, depositors, and bondholders receive the value proportional to their shares in the LTL. When there are the necessary funds, they receive the total they have the right to. If the cash generated by earnings is insufficient to cover the depositors, bondholders, and open market, financial distress is characterized in $t_{2}$.

It is worth mentioning that, in banks, the total term deposits classified in LTL are not expected to be linked to high liquidity assets, since they involve funds that are remunerated based on a particular waiting period. In 2008 , term deposits without any advanced repayment clause represented, on average, $30 \%$ of total recorded term deposits, according to CB data (http://www.bcb. gov.br/Fis/Estdeprazo/estprazo.asp).
Having indicated financial distress and/or that the bank's financial situation has been compromised, a merger consists of an alternative for the organization to continue operating in $t_{2}$. For restructuring to occur, however, there needs to be interest on the part of an acquirer. Based on Bulow and Shoven (1978), a merger is feasible for an acquirer if the target bank presents a cash value generated by profits, plus tax benefits minus depositor and bondholder expenses, that is greater than the value payable to the creditor institutions belonging to the money market:

$$
\Phi+\left(K_{2}-L\right) \times \tau-\left(1+r_{D}\right) \times D_{2}>\Phi \times\left(\frac{B_{2}}{D_{2}+B_{2}}\right)
$$

in which $K_{2}$ is the tax loss accumulated in $t_{2}$ and $\tau$ is the tax rate applicable to profit minus depreciation and interest paid.

\section{EMPIRICAL ANALYSIS: THE ITAÚ-UNIBANCO CASE}

To facilitate the understanding of the equations quantified in this section, Table 1 presents Unibanco's Summarized Balance Sheet containing the value of the main accounts used in this study and their share percentages.

Table 1

Unibanco's summarized individual Balance Sheet (BS) relating to September 30 th , 2008

\begin{tabular}{|c|c|c|c|c|c|}
\hline \multicolumn{3}{|c|}{ Current assets } & \multicolumn{3}{|c|}{ Current liabilities } \\
\hline Item & $\begin{array}{c}\text { Value } \\
\text { (R\$ billion) }\end{array}$ & $\begin{array}{l}\text { Total assets } \\
(\%)\end{array}$ & Item & $\begin{array}{c}\text { Value } \\
\text { (R\$ billion) }\end{array}$ & $\begin{array}{c}\text { Total assets } \\
(\%)\end{array}$ \\
\hline Available cash & 1.6 & 0.9 & Deposits & 32.3 & 17.3 \\
\hline Liquid interbank investments & 39.1 & 21.0 & Interbank & 4.4 & 2.4 \\
\hline $\begin{array}{l}\text { Open market (lending or banked } \\
\text { position) }\end{array}$ & 9.0 & 4.8 & Open market funding & 32.2 & 17.3 \\
\hline In financial deposits & 7.3 & 3.9 & $\begin{array}{l}\text { Funds from acceptances and } \\
\text { endorsements }\end{array}$ & 6.1 & 3.3 \\
\hline In foreign currency & 0.0 & 0.0 & Interbank relations & 0.9 & 0.5 \\
\hline $\begin{array}{l}\text { Market securities and derivative } \\
\text { instruments }\end{array}$ & 19.8 & 10.6 & Interdependence relations & 0.3 & 0.2 \\
\hline Own portfolio & 7.7 & 4.1 & Loan obligations & 5.7 & 3.1 \\
\hline $\begin{array}{l}\text { Linked to the Central Bank of } \\
\text { Brazil (CB) }\end{array}$ & 5.1 & 2.7 & Local onlending obligations & 3.0 & 1.6 \\
\hline $\begin{array}{l}\text { Object of repos with free } \\
\text { movement }\end{array}$ & 0.2 & 0.1 & Foreign onlending obligations & 0.0 & 0.0 \\
\hline Interbank relations & 7.2 & 3.9 & Derivative financial instruments & 7.6 & 4.1 \\
\hline Deposits at the CB & 6.4 & 3.4 & Other obligations & 9.4 & 5.0 \\
\hline Interdependence relations & 0.0 & 0.0 & \multicolumn{3}{|c|}{ Long term liabilities } \\
\hline Credit operations & 26.6 & 14.3 & Deposits & 39.9 & 21.4 \\
\hline Leasing operations & 0.4 & 0.2 & Interbank & 12.5 & 6.7 \\
\hline
\end{tabular}


Tabela 1

Cont.

\begin{tabular}{|c|c|c|c|c|c|}
\hline \multicolumn{3}{|c|}{ Current assets } & \multicolumn{3}{|c|}{ Current liabilities } \\
\hline Item & $\begin{array}{c}\text { Value } \\
\text { (R\$ billion) }\end{array}$ & $\begin{array}{l}\text { Total assets } \\
(\%)\end{array}$ & Item & $\begin{array}{c}\text { Value } \\
\text { (R\$ billion) }\end{array}$ & $\begin{array}{c}\text { Total assets } \\
(\%)\end{array}$ \\
\hline Other credits & 11.8 & 6.4 & Open market funding & 11.0 & 5.9 \\
\hline Tax credits & 0.7 & 0.4 & $\begin{array}{l}\text { Funds from acceptances and } \\
\text { endorsements }\end{array}$ & 2.7 & 1.5 \\
\hline Other values and goods & 0.4 & 0.2 & Loan obligations & 2.3 & 1.2 \\
\hline \multicolumn{3}{|c|}{ Long term realizable assets } & Local onlending obligations & 6.6 & 3.5 \\
\hline Liquid interbank investments & 1.0 & 0.5 & Foreign onlending obligations & 0.7 & 0.4 \\
\hline $\begin{array}{l}\text { Market securities and derivative } \\
\text { instruments }\end{array}$ & 33.5 & 18.0 & Derivative financial instruments & 0.7 & 0.4 \\
\hline Interbank relations & 0.1 & 0.0 & Other obligations & 12.5 & 6.7 \\
\hline Credit operations & 20.2 & 10.9 & Deferred income & 0.4 & 0.2 \\
\hline Leasing operations & 0.3 & 0.2 & Net equity & 12.9 & 6.9 \\
\hline Other credits & 3.0 & 1.6 & Total liabilities & 186.3 & 100.0 \\
\hline Tax credits & 1.9 & 1.0 & & & \\
\hline Other values and goods & 0.4 & 0.2 & & & \\
\hline Permanent & 20.7 & 11.1 & & & \\
\hline Total assets & 186.3 & 100.0 & & & \\
\hline
\end{tabular}

Source: Elaborated by the authors based on Unibanco's BS.

\subsection{Unibanco's Liquidation Conditions}

\subsubsection{Bankruptcy costs}

To quantify the conditions indicative of liquidation, given by inequation 1, this study first estimates Unibanco's bankruptcy costs. Unibanco's bankruptcy expenses were estimated at $\mathrm{R} \$ 9.4$ billion, as according to equation 6 , or $5 \%$ of the FI's assets, measured on September $30^{\text {th }}$ of 2008 (Unibanco, 2008b), the date of the last BS before the merger.

$$
B C=P-L=28.2-18.8=9.4 \text { billion }
$$

Unibanco's profit $(P)$ was measured based on discounted cash flow on September $30^{\text {th }}$ of 2008 . The net present value (NPV) in a company is equal to the expected value of the future discounted free cash flow (FCF). The FCF reflects the flow of funds generated by the company that is available for the company's loan and capital fund providers. Therefore, this is an adequate method for estimating the profits to be distributed among the claimant classes (Trevisan Auditores e Consultores Ltda. - Trevisan,
2003). Dermine (2010) states that banks can be evaluated via the discount on future economic profits. Brazilian Securities and Exchange Commission Instruction n. 361/2002 (CVM, 2002) considers discounted cash flow among its evaluation methodologies.

The present value of Unibanco's FCF, of R $\$ 28.5$ billion, was estimated using projections of operational gains after tax for the five years subsequent to September $30^{\text {th }}$ of 2008 , obtained using $1^{\text {st }}$ order autoregressive models [AR(1)]. The residual value after the fifth year considered a growth rate of profits equal to 0 . The discount rate of the bank's projected FCF, of $15.9 \%$ a year, given by its cost of own capital, was measured using the international Capital Asset Pricing Model (CAPM). In 2008, by means of a new holding, Itaú bought the shares at a slightly higher price than estimated, at around $\mathrm{R} \$ 29$ billion.

The construction of the $A R(1)$ model used Unibanco's income derived from financial intermediation and other operating revenues/expenses after revenues, expenses, and tax in the last eight years up to September $30^{\text {th }}$ of 2008 , obtained in IF.data of the CB (https://www3.bcb.gov.br/ ifdata/), as shown in Figure 1. 


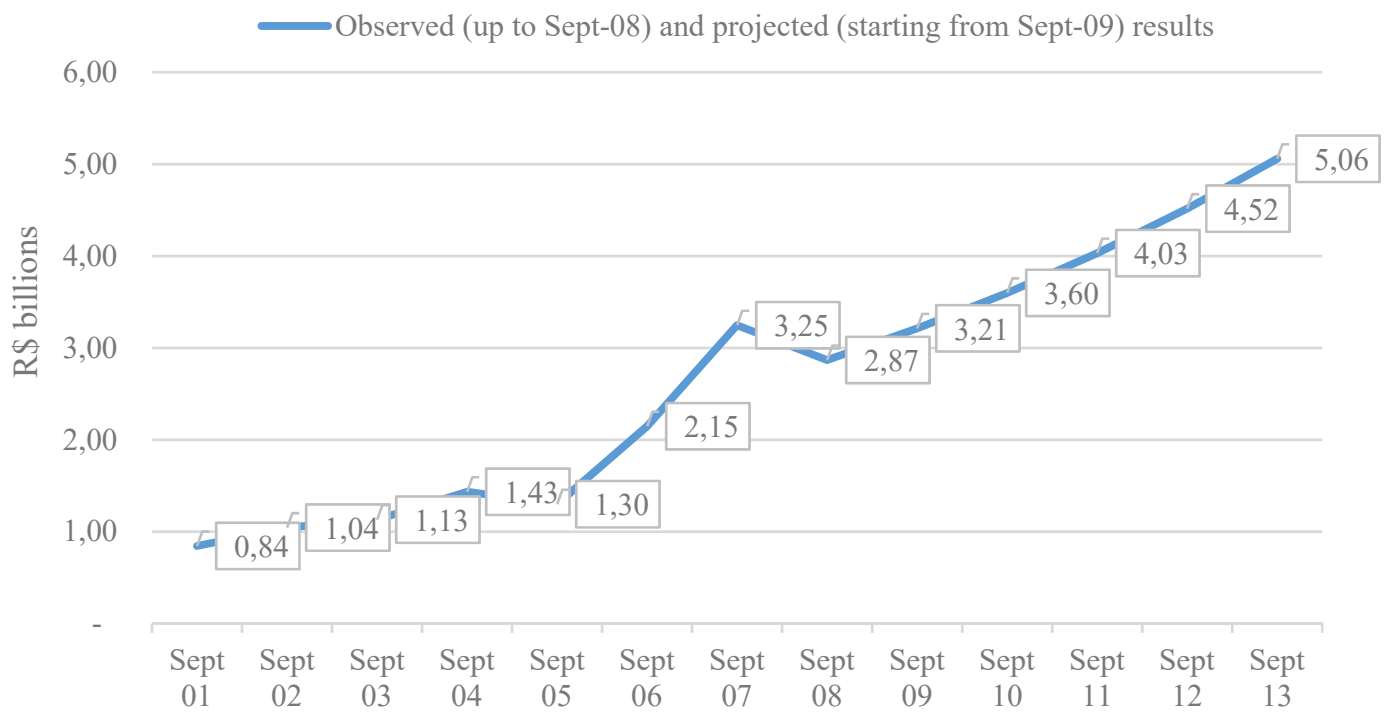

Figure 1 Unibanco's annual operating income minus taxes Source: If.data of the Central Bank of Brazil.

The parameters of the model, estimated using the ordinary least squares (OLS) method, and the results of the main regression tests, with a 95\% confidence interval (CI) and 94\% overall adjustment level, are found in Table 2.

Table 2

Coefficient and results of the Unibanco profit regression tests - $1^{\text {st }}$ order autoregressive model [(AR) 1]

\begin{tabular}{lccccc}
\hline Variable & Coefficient & Standard error & t stat & p-value & R-squared \\
\hline$Y_{(t-1)}$ & 1.1202 & 0.1204 & 9.3007 & 0.0001 & 0.9351 \\
\hline
\end{tabular}

Source: Elaborated by the authors based on the results of the regression.

The statistical premises, such as those related to stationarity and serial autocorrelation (Box, Jenkins, \& Reinsel, 2008), were met. The augmented Dickey-Fuller (ADF) test with constant and tendency indicated, with a $1 \%$ level of significance, the stationarity in level of the series lagged by one period. The other usual tests used to evaluate the presence of a unitary root, such as the Phillips and Perron (PP) and the Kwiatkowski, Phillips, Schmidt, and Shin (KPSS) tests, corroborate the stationarity. The autocorrelation function (ACF) showed how strong the observed value correlates with the one presented in a previous period. The Akaike information criterion (AIC), for order selection, reinforced the conclusion that the best adherence of the model was obtained with the oneperiod lag.

The calculation of the present value of the FCF also needs an estimate of the discount rate. According to Dermine (2010), the discount rate to be used when evaluating banks is the cost of own capital. In an assessment of Unibanco, Trevisan (2003) considers the costs of own capital as the discount rate. The pricing of the risk asset was estimated using the CAPM model from Sharpe-Lintner (Ingersoll, 1987), as according to equation 7,

$$
\left[E\left(R_{i}\right)-R_{f}\right]=\beta \times\left[E\left(R_{M}\right)-R_{f}\right]
$$

in which $\left[E\left(R_{i}\right)-R_{f}\right]$ is the risk premium expected from investing in the bank's stocks and $\left[E\left(R_{M}\right)-R_{f}\right]$ is the expected market risk premium.

In this study, the CAPM was estimated based on variables from the international financial market and on the premiums for the risk in investing in a particular country (Sercu, 1980; Solnik, 1983; Trevisan, 2003). The proposed methodology is based on a CAPM for the United States; that is, the variables are estimated for that market. The Brazilian stock market presents low liquidity and high business variability, as well as not having an appropriate risk-free asset for estimating the model in Brazil. From this perspective, the 10-year US Treasury Note interest 
rate $\left(R_{f}\right)$ constitutes a proxy for zero-risk return and Standard \& Poor's 500 (S\&P 500) represents the market return $\left[E\left(R_{M}\right)\right]$. In addition, the country-risk premium and the currency-risk premium may be considered.

The temporal cut-off for the data collection for the regression of the international CAPM, obtained from the Investing.com website (https://br.investing.com/), precedes the merger. The daily data refer to the period from November $16^{\text {th }}$ of 2006 to October $31^{\text {st }}$ of 2008 (469 observations). The variations in the ordinary share quotations of Unibanco, , and of the S\&P $500\left[E\left(R_{M}\right)\right]$, were accumulated in 252 days and the 10-year US Treasury Note rates, $R_{f}$, are in percentage per year (p.a.). The series used in the regression, therefore, ran from November $26^{\text {th }}$ of 2007 to October $31^{\text {st }}$ of 2008 (219 observations). The parameters and the results of the regression test of the international CAPM with a $95 \%$ CI and $35 \%$ overall adjustment level are presented in Table 3.

Table 3

Coefficient and results of the regression tests of the U.S. Capital Asset Pricing Model (CAPM)

\begin{tabular}{lccccc}
\hline Variable & Coefficient & Standard error & t-stat & p-value & R-squared \\
\hline$E\left(R_{M}\right)-R_{f}$ & 1.4409 & 0.1321 & 10.9039 & $2.33387 \mathrm{E}-22$ & 0.3540 \\
\hline
\end{tabular}

Source: Elaborated by the authors based on the results of the regression.

Having estimated the parameters, the result is $15.9 \%$ per year for Unibanco's cost of own capital, leaving the variables of equation 7 to be calculated, as well as the country and currency risk. The 5-year temporal cut-off (from 2008 to 2013) was considered as it was shown to be sufficient to accommodate high and low cycles in the U.S. stock market.

Thus, the 10-year US Treasury Notes were accumulated in the five years ( 1,260 days) following the merger, that is, from November $4^{\text {th }}$ of 2008 to November $8^{\text {th }}$ of 2013 , and annualized, reaching $2.7 \%$ p.a. Also, the market risk premium, given by the mean of the difference between the variation in the S\&P 500 (6.5\% p.a.) and in the 10 year US Treasury Notes (2.6\% p.a.), was calculated at 3.9 percentage points (p.p.) in this period. Finally, the mean of the Embi+ $\left(R_{B}\right)$ was 2.3 p.p. and the annual mean currency variation $\left(R_{X}\right)$ in the period was $5.4 \%$. The currency risk calculated is within the estimates presented by the literature (Luamoto, 2009; Trevisan, 2003).

$$
E\left(R_{i}\right)=R_{f}+\beta \times\left[E\left(R_{M}\right)-R_{f}\right]+R_{B}+R_{X}=2.7+1.4 \times 3.9+2.3+5.4=15.9
$$

Equation 9 presents the estimate of Unibanco's expected profit on October $31^{\text {st }}$ of 2008 , on the eve of the merger, the base date of this study. In section 4.1.5 (Simulations), the $P$ values are simulated.

$$
\begin{gathered}
P=\frac{\Phi_{1}}{\left(1+R_{i}\right)}+\frac{\Phi_{2}}{\left(1+R_{i}\right)^{2}}+\frac{\Phi_{3}}{\left(1+R_{i}\right)^{3}}+\frac{\Phi_{4}}{\left(1+R_{i}\right)^{4}}+\frac{\Phi_{5}}{\left(1+R_{i}\right)^{5}}+\frac{\Phi_{5}}{\left(R_{i}\right)} \\
P=\frac{3.2}{(1.159)}+\frac{3.6}{(1.159)^{2}}+\frac{4.0}{(1.159)^{3}}+\frac{4.5}{(1.159)^{4}}+\frac{5.0}{(1.159)^{5}}+\frac{5.0}{(0.159)}=R \$ 28.2 \text { billion }
\end{gathered}
$$

Besides the cash generated by the bank's earnings, the bankruptcy costs estimate requires the liquidation value of its assets $L$ to be calculated. For a FI, the $L$ proxy should take into account the market value of its credit portfolio. In Unibanco, the total credit operations (except tax-related ones) totaled $\mathrm{R} \$ 59.8$ billion on September $30^{\text {th }}$ of 2008, discounting provisions. This value is the result of the sum of the items "Credit Operations", which was R\$ 46.7 billion, "Leasing Operations", R $\$ 686.6$ million, and "Other Credits" (except tax-related ones of R $\$ 2.5$ billion), $\mathrm{R} \$ 12.3$ billion, according to the current and long-term assets of the BS on September $30^{\text {th }}$ of 2008 (Unibanco, 2008 b). These values are also presented in Unibanco's Summarized Balance Sheet (Table 1).
Also regarding the determination of Unibanco's liquidation value, permanent assets are considered, amounting to $\mathrm{R} \$ 20.7$ billion. The total value of "Other Values and Goods", which should also be considered, is given by the sum of the value recorded in CA, of $\mathrm{R} \$ 356.3$ million, and in long-term realizable assets, of $\mathrm{R} \$ 436.4$ million (Unibanco, 2008b), totaling R $\$ 792.6$ million. Credit operations, permanent assets, and other values and goods therefore amounted to $\mathrm{R} \$ 81.3$ billion.

The tendency for firms in financial distress is to sell their goods and rights at a discount in relation to book value (Fisher \& Martel, 2009). Mason (2005) and Bennett and Unal (2014) estimated a devaluation of around $18 \%$ on the goods and rights of banks in difficulties. From this 
perspective, these assets would be evaluated at $\mathrm{R} \$ 66.7$ billion. It is necessary to subtract from the liquidation value of Unibanco's assets the FI's obligations in the form of loans, local and foreign onlending, and derivatives, among other obligations, such as tax and social security ones, amounting to $\mathrm{R} \$ 47.9$ billion (Unibanco, 2008b). In the end, therefore, the liquidation value of the goods and rights minus the obligations and derivatives was estimated at $\mathrm{R} \$ 18.8$ billion.

\subsubsection{Expected value payable to depositors and bondholders in the event of bankruptcy $\left(D_{b}\right)$}

According to Bulow and Shoven (1978), in the event of bankruptcy, liquid assets or cash $(C)$ plus the liquidation value of goods, rights, and obligations $(L)$ are distributed proportionally among depositors and creditor banking institutions, as according to equation 3 . The liquidation value of the goods and rights minus the obligations of the bank, of R $\$ 18.8$ billion, added to its liquid assets, of $\mathrm{R} \$ 37.4$ billion (Unibanco, 2008b), whose details from the considered items shown in the Summarized Balance Sheet (Table 1) are presented in the next paragraph, totaled $\mathrm{R} \$ 56.1$ billion on September $20^{\text {th }}$ of 2008 . This amount, of $\mathrm{R} \$ 56.1$ billion, was insufficient to pay the depositors and bondholders $\left(D_{1}+D_{2}\right)$ and creditor banks $\left(B_{1}\right)$. In this case, the depositors and bondholders $\left(D_{b}\right)$ would receive $\mathrm{R} \$ 33.9$ billion.

$$
\begin{gathered}
C+L<\left(D_{1}+D_{2}+B_{1}\right) \times\left(1+r_{D}\right) \\
37.4+18.8<(34.0+21.8+36.6) \times(1,112) \\
R \$ 56.1 \text { billion }<R \$ 102.9 \text { billion }
\end{gathered}
$$$$
D_{b}=\frac{D_{1}+D_{2}}{D_{1}+D_{2}+B_{1}}(C+L)=\frac{34.0+21.8}{34.0+21.8+36.6}(37.4+18.8)=R \$ 33.9 \text { billion }
$$

The proxy for cash $(C)$, calculated at $\mathrm{R} \$ 37.4$ billion, was inspired by the concept of the Liquidity Index used in the CB Financial Stability Report (CB, 2018), which considers the sum of high liquidity assets and mandatory deposits. It therefore covers the item "Available Cash", presented in Unibanco's BS (Unibanco, 2008b), with R\$ 1.6 billion. The free cash reserves of the FIs at the $\mathrm{CB}$ are classified in this account, as explained by Cosif (CB, 1987).

Also, of the "Liquid Interbank Investments" classified in CA, the collateral received from repo operations carried out in the open market (lending or banked position), of $\mathrm{R} \$ 9$ billion, the investments in interbank deposits, of $\mathrm{R} \$$ 7.3 billion, and in foreign currency, of $\mathrm{R} \$ 28.9$ million, are all considered. Of the "Market Securities and Derivative Instruments" of CA, the own portfolio, of R $\$ 7.7$ billion, those that are the object of repos with free movement, of $\mathrm{R} \$ 209.1$ million, and those linked to the $\mathrm{CB}$, of $\mathrm{R} \$$ 5.1 billion, are all considered, the latter of which include mandatory deposits in bonds, from "Interbank Relations", the deposits at the $\mathrm{CB}$, of $\mathrm{R} \$ 6.4$ billion, which contain the mandatory deposits in cash.

The value of $D_{1}$, as according to equation 3 presented in the section on the method, represents the value of the principal of the deposits (except interbank deposits) and of the bonds issued by the bank ("Funds from Acceptances and Endorsements" item), maturing in $t_{1}$ (classified in the CL of the BS). According to Unibanco's BS (Unibanco, 2008b) and Table 1 - Summarized Balance Sheet - this value totaled $\mathrm{R} \$ 34$ billion.

The value of $D_{2}$ should also reflect the principal of the deposits (except interbank ones) and of the bank bonds
("Funds from Acceptances and Endorsements") maturing in $t_{2}$ and that can be withdrawn/redeemed by the client/ investor. Therefore, $D_{2}$ was calculated based on the BS data (Unibanco, 2008b), represented by Table 1 - Summarized Balance Sheet - via the sum of the fraction of deposits, except interbank ones (70\% of R $\$ 27.4$ billion $=\mathrm{R} \$ 19.2$ billion), with the total of the securities classified in LTL ( $\mathrm{R} \$ 2.7$ billion), totaling $\mathrm{R} \$ 21.9$ billion. In 2008, deposit contracts with an advance redemption clause represented, on average, $70 \%$ of total term deposits recorded at the Clearing House for the Custody and Financial Settlement of Securities (Cetip), according to CB statistics (CB, 2017); for this reason, the $70 \%$ fraction was considered in the $\mathrm{D}_{2}$ calculation.

The face value payable to the creditor FIs of the bank in distress in $t_{1}\left(B_{1}\right)$, represented by the funds raised on the open and interbank money market classified in CL, as equation 3 indicates, reached $\mathrm{R} \$ 36.6$ billion (Unibanco, 2008b) (Table 1 - Summarized Balance Sheet). Finally, given the representativeness of the term deposits, of $70.3 \%$ (Unibanco, 2008b) of total deposits (except interbank) and of bonds, the Bank Deposit Certificate (BDC) rate, obtained from the Time Series Management System on the CB website, accumulated in the 12 months up to October $31^{\text {st }}$ of 2009 , considered the deposits and bonds $\left(r_{D}\right)$.

\subsubsection{Expected value payable to depositors and bondholders in the event of continuity $\left(D_{c}\right)$}

In the event of continuity, the values that the claimants receive depend on the cash $(C)$, in $t_{1}$ and on the bank's future results $(P)$, in $t_{2}$, as presented in 
equation 4. From analyzing each period separately, it is noted that, in, Unibanco's liquid assets $(C)$ were lower than its commitments, of $\mathrm{R} \$ 78.2$ billion, to the creditor banks $\left.\left[\left(1+r_{B}\right) \times B_{1}\right)\right]$, as well as to the depositors and holders of the bank's bonds $\left(D_{1}+r_{1}\right)$ maturing in $t_{1}$. This insufficiency of funds is demonstrated by equation 12 , whose variable values were obtained from Unibanco's BS, more specifically from CL (Unibanco, 2008b), represented by Table 1 - Summarized Balance Sheet,

$$
C=\left(1+r_{B}\right) \times B_{1}+r_{1}+D_{1}
$$

in which $r_{B}$ is the interest rate charged by the creditor institutions of the bank that participate in the open and interbank market, represented by the CDI rate accumulated in the 12 months up to October $31^{\text {st }}$ of 2008, obtained from the CB Time Series Management System.

$$
\begin{gathered}
37.4<(1.119) \times 36.6+3.2+34.0 \\
R \$ 37.4 \text { billion }<R \$ 78.2 \text { billion }
\end{gathered}
$$

Equation 12 replicates equation 10 of the original model from Bulow and Shoven (1978, p. 443). The result of equation 12 indicates the need for additional funds for the bank in difficulties predominantly provided by its creditor FIs. It is worth remembering that the proxy used for the interest rate charged by the FIs participating in the open and interbank market $\left(r_{B}\right)$ was the IDC accumulated in the 12 months up to October $31^{\text {st }}$ of 2008.

In $t_{2}$, Unibanco's profit $(P)$, calculated by equation 9, was insufficient to cover $70 \%$ of the deposits (except interbank ones) and the total bonds issued $\left[\left(1+r_{D}\right) \times D_{2}\right]$, as well as to pay the creditor institutions participating in the open and interbank market $\left[\left(1+r_{D}\right) \times B_{2}\right]$. This insufficiency of funds is demonstrated by equation 13 , whose variable values were obtained from Unibanco's BS, more specifically from LTL (Unibanco, 2008b), represented in summary in Table 1 - Summarized Balance Sheet. Equations 12 and 13 suggest Unibanco being in financial distress for two consecutive periods, $t_{1}$ and $t_{2}$.

$$
\begin{gathered}
P<\left(D_{2}+B_{2}\right) \times\left(1+r_{D}\right) \\
28.2<(21.9+23.5) \times(1.112) \\
R \$ 28.2 \text { billion }<R \$ 50.5 \text { billion }
\end{gathered}
$$

Since Unibanco's earnings were insufficient to cover its obligations in $t_{2}$, as shown by equation 13 , its depositors and bondholders receive a value proportional to their respective shares in LTL. Equation 14, which is equivalent to the first three terms in equation 4 , estimates the value payable to the depositors (except interbank deposits) and to the holders of Unibanco bonds at R\$ 49.4 billion.

$$
\begin{gathered}
D_{C}=r_{1}+D_{1}+\frac{D_{2}}{\left(D_{2}+B_{2}\right)(1+i)} \int_{0}^{\left(D_{2}+B_{2}\right)\left(1+r_{D}\right)} \Phi f(\Phi) d \Phi+\frac{D_{2}\left(1+r_{D}\right)}{1+i} \int_{\left(D_{2}+B_{2}\right)\left(1+r_{D}\right)}^{\infty} f(\Phi) d \Phi \\
\mathrm{D}_{\mathrm{C}}=\mathrm{r}_{1}+\mathrm{D}_{1}+\left[\left(\frac{\mathrm{D}_{2}}{\left(\mathrm{D}_{2}+\mathrm{B}_{2}\right)(1+\mathrm{i})}\right) \times(\mathrm{P})\right] \\
D_{c}=3.2+34.0+\frac{21.9}{(21.9+23.5)(1.1194)} \times 28.2=R \$ 49.4 \text { billion }
\end{gathered}
$$

The discount rate used by the bank's creditors from the open and interbank market $(i)$ is represented by the Special System of Liquidation and Custody (Selic) market rate, obtained from the CB Time Series Management System. For $r_{1}$, which consists of the value of the interest applicable to the deposits (except interbank) and to the bonds issued by Unibanco, the interest rates accumulated in the 12 months up to October $31^{\text {st }}$ of 2008 were multiplied by the respective balances (Unibanco, 2008b): 0\% interest rate applicable to cash deposits; $7.6 \%$ to savings; $11.2 \%$ (Pre-BDC) to term deposits; and 11\% (93\% of the IDC) to bonds. According to the footnotes (Unibanco, 2008b), the real estate and agribusiness credit bills were remunerated by up to $93 \%$ of the IDC and represented $71.7 \%$ of the "Funds from Acceptances and Endorsements" item of CA.

\subsubsection{Conditions for liquidation of Unibanco}

According to the estimates applied to the bankruptcy condition, shareholders and creditor banks of Unibanco would maximize their joint utility with the bank's liquidation.

$$
\begin{array}{r}
B C+D_{b}>D_{c} \\
9.4+33.9<49.4
\end{array}
$$

$R \$ 43.3$ billion $<R \$ 49.4$ billion

In the event of bankruptcy, $\mathrm{R} \$ 43.3$ billion would be spent to pay $\mathrm{R} \$ 33.9$ billion to Unibanco's depositors (except interbank depositors, who form part of the creditor banks group) and bondholders, as well as to cover the bankruptcy costs of $\mathrm{R} \$ 9.4$ billion. The bank's permanence in the market 
would require $\mathrm{R} \$ 49.4$ billion. The difference between the payments, of $6 \%$ of $\mathrm{CA}$, prompted the simulation below of the expected earnings and of the value raised from the sale of the bank's goods and rights net of its obligations.

\subsubsection{Simulations}

As in the classic article, but based on real variables, this section simulates the present value of Unibanco's expected earnings, $P$, and the liquidation value of its goods and rights net of its obligations, $L$. When simulating $P$, continuity is warranted starting at $\mathrm{R} \$ 32.1$ billion, $13.9 \%$ above the profit estimated in this research, because the bankruptcy costs increase more than the deposits and debts payable in the event of continuity, making it cheaper to continue. Figure 2 shows the behavior of the expected value of the deposits and bonds $(D E)$ depending on $P$, suggesting that the higher the earnings, the greater the probability of the company continuing.

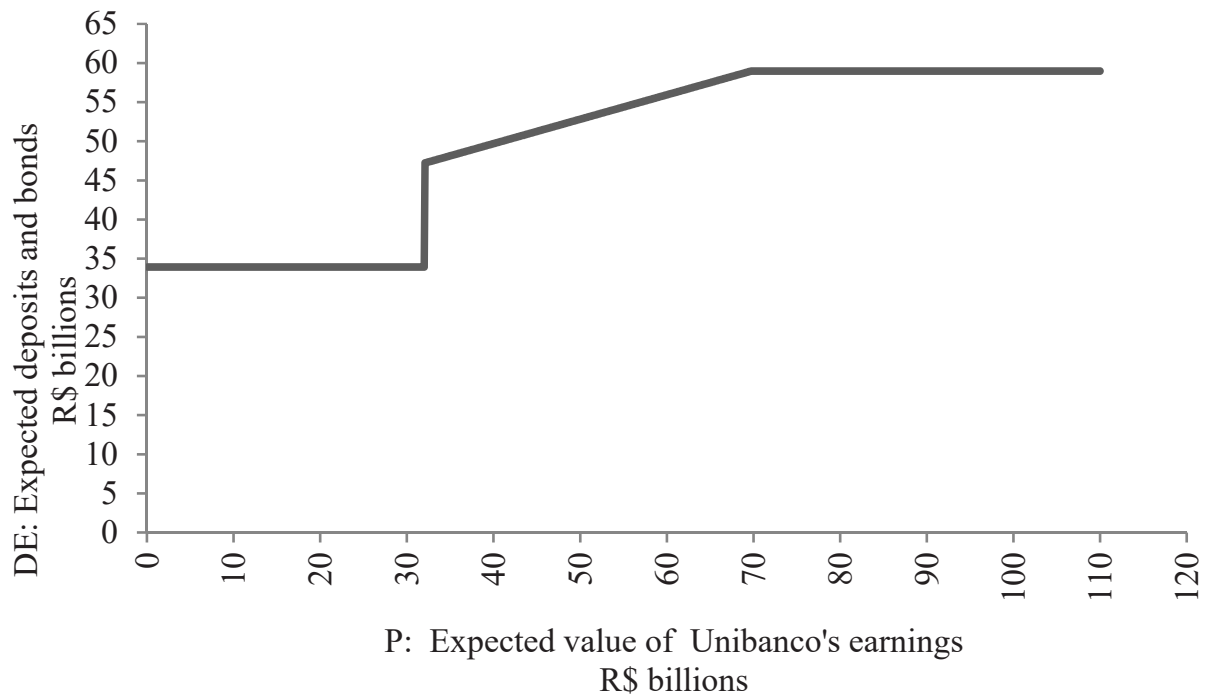

Figure 2 Expected value of Unibanco's deposits and bonds

Source: Own elaboration based on Bulow and Shoven (1978).

Continuity maximizes the shareholders' and money market participants' utility for $L$ values $36.6 \%$ lower than estimated. With a reduction in $L$, bankruptcy costs increase more than proportionally than the reduction in deposits and bonds in the event of bankruptcy, making continuity less costly. Figure 3, which is similar to that of Bulow and Shoven (1978), suggests that the higher $L$ is, the greater the proximity in relation to bankruptcy.

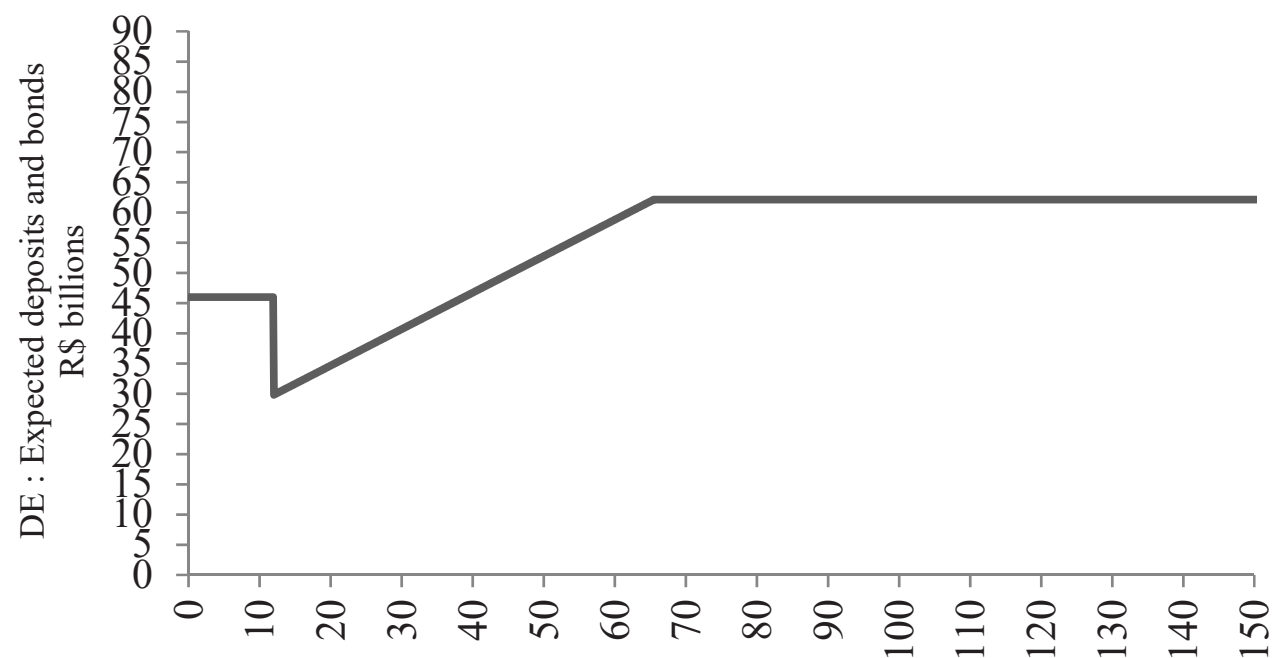

L: Liquidation value of Unibanco's goods, rights and obligations

$\mathrm{R} \$$ billions

Figure 3 Expected value of Unibanco's deposits and bonds

Source: Own elaboration based on Bulow and Shove (1978). 


\subsubsection{Conditions for merger with Itaú}

Having indicated the signs of Unibanco's compromised financial situation, a merger consists of an alternative to remain in the market in $t_{2}$. A union may be advantageous for buyers in M\&A events due to the tax credit derived from the acquired firm, as shown in inequation 5 . The tax credits are based on the intertemporal differences between the accounting and taxable income and on tax losses (Unibanco, 2008b). Unibanco's net tax credit totaled R\$ 2.5 billion on September $30^{\text {th }}$ of 2008 (Unibanco, 2008b).

In addition, there is the tax benefit derived from the positive difference between the value paid to buy control of the acquired party and the net value, on the data of acquisition, of the identifiable assets acquired and the liabilities assumed $(F)$, based on their fair value. Law n. 9,532 of December $10^{\text {th }}$ of 1997 grants companies the right to recover part of the excess price paid through amortization of the premium in the calculation of real income. The value of the premium, posted as an expense, reduces income and the basis for calculating tax payments. The merger operation in question was carried out for a value of around $\mathrm{R} \$ 29$ billion and shares were issued at $\mathrm{R} \$$ 12 billion, generating a capital gain linked to the existence of the premium, of $\mathrm{R} \$ 17$ billion, as reported in the ruling of the Board of Tax Appeals - Carf (2017, p. 45).

Inequation 16 represents the merger condition, considering the benefit derived from the acquisition premium $(F)$.

$$
\begin{gathered}
\Phi+\left(K_{2}-L\right) \times \tau+F-\left[\left(1+r_{D}\right) \times D_{2}\right]>\Phi \times\left(\frac{B_{2}}{D_{2}+B_{2}}\right) \\
28.2+2.5+17.6-(1+0.1121) \times 21.9>28.2 \times\left(\frac{23.5}{21.9+23.5}\right) \\
R \$ 24.0 \text { billion }>R \$ 14.6 \text { billion }
\end{gathered}
$$

Itaú would choose the acquisition based on the taxed credits provided by Unibanco. The tax authorities, however, may contest the amortized premium and have claimed $\mathrm{R} \$ 18.7$ billion from Itaú-Unibanco in taxes related to the accounting instruments used to merge the operations,
$\mathrm{R} \$ 1.1$ billion of which are in fines. Up to now, the case has not been judged. If the incentive corresponding to the acquisition premium were disregarded, the merger would not be justified.

\section{RESULTS ANALYSIS}

The theoretical-algebraic model proposed by Bulow and Shoven (1978), supported by agency theory, was adjusted to the idiosyncrasies of commercial banks and proved adequate for explaining the merger occurring between Unibanco and Itaú. According to the tool, the proxies, and the respective estimates adopted, the results indicate that Unibanco was experiencing financial distress and bankruptcy circumstances. In addition, there was evidence that the tax gains for an acquirer, in this case Itaú, incentivized the merger.

Unibanco's bankruptcy costs added to the value payable to the depositors (except interbank ones, which form part of the creditor banks group) and bondholders were lower, by $3.2 \%$ of assets, than the value payable to these classes in the event of continuity. Since the bank's liquidation would imply lower costs, it constitutes an option for maximizing the joint utility of the shareholders and creditor banks from the open money and interbank market. In this context, banks tend to interrupt the supply of funds for the FI to continue operating, thus forcing bankruptcy.

If on one hand liquidation maximizes the utility of the alliance between shareholders and creditor banks, depositors and bondholders would receive more in the event of continuity, which raises the conflict of interests between the classes. The bankruptcy costs, estimated at $\mathrm{R} \$ 9.4$ billion (5\% of assets), were decisive for signaling the unsustainability of maintaining Unibanco in the market without corporate restructuring. According to Hardy (2013), the administrative costs associated with bankruptcy amount to $7 \%$ of pre-liquidation bank assets.

If the present value of the expected profits $P$ were $13.9 \%$ greater than estimated, continuity would maximize the utility of the shareholders and open market. A 36.6\% lower $L$ value would also favor continuity. These simulations, also carried out in the reference article (Bulow \& Shoven, 1978), suggest that the higher the expected earnings and lower the liquidation value, the greater the probability of the company continuing.

The merger presented the conditions for Itaú to acquire Unibanco based on the tax gains due, in particular, to the fiscal benefit derived from the acquisition premium. The total tax credits added to the expected value of earnings exceeded the value payable to the depositors, bondholders, and creditor banks, by R $\$ 9.4$ billion (5\% of Unibanco's total assets). 


\section{CONCLUSIONS}

The mathematical framework proposed by Bulow and Shoven (1978) is characterized by its theoretical robustness and stands out for highlighting the role of creditor banks in the prospects for the company's continuity or closure. In the model adjusted for commercial banks proposed in this study, as well as in practice, the liquidity exchange between FIs also constitutes an essential element for regulating the functioning of banks.

Using the model adjusted to banks as a tool and the estimates adopted, the evidence indicated that the merger between Itaú and Unibanco was explained by Unibanco's financial vulnerability, which contributes to merging with a solid organization. Evidence of Unibanco's financial distress was also found in a study that evaluates the performance of banks using multiattribute modeling based on the optimization process under maximum entropy (Gartner, 2015). Unibanco's indices deteriorated in 2006 and 2007, when it moved into the extreme risk group. In 2008, now as Itaú-Unibanco, it moved to the high risk group.

From the acquirer's perspective, the merger conditions, based on tax gains, were also verified. The tax credit derived from the acquisition premium made the merger feasible. The abovementioned benefit, however, is being contested by the Brazilian Federal Revenue. It is also worth remembering that operational and financial synergies provided by the acquisition (Hankir, Rauch, \& Umber, 2011) favor mergers such as the one occurring between the banks in question. This does not take into account that the incorporation of Unibanco would put Itaú in the position of biggest private Brazilian bank, making it strong in the face of the competition presented with the entry of foreign banks.

This study contributed to academic as well as practical epistemology, especially as it adjusts the classical bankruptcy and merger model, encapsulated in a consolidated theory, to commercial banks. Besides this novel methodology, it applies it to an emblematic case, reinforcing agency theory and the method's effectiveness. This therefore implies a useful tool for academia, for agents involved in decisionmaking processes, and for bank supervision. The FSB (2014) recommends that local legislations contemplate the authority needed for supervisors to resolve FIs in an ordered manner, without losses to the taxpayer and maintaining essential services. In this context, central banks should incentivize private solutions, such as M\&A, which aim to restructure the businesses of banks in crisis and attenuate the risk of contagion.

As limitations of the research, the authors themselves, Bulow and Shoven (1978), recognize that the model developed should be understood as part of a broader framework that considers other aspects related to corporate financial decisions. The hierarchy for receiving a firm's residual values, for example, could have effects on the choices of the claimant classes in the direction of bankruptcy or towards a merger.

In light of the conclusions, it is recommendable to advance the theme in order to widen the insolvency and merger model for banks. With the econometric tool, it is possible to build a model for predicting banking crises and propose alternatives that do not lead to financial costs, such as a supervised merger. Despite the precision of the results of the bankruptcy prediction models in the literature, the choice of the model and of the explanatory variables remains in discussion, as well as finding theories that explain the phenomenon. The factors indicated as relevant in this study should be tested: bankruptcy costs, expected earnings, liquid assets, short and long term debts, and the bank's liquidation value. In addition, other variables should be detected, besides tax credits, that would contribute to a robust organization acquiring an insolvent bank.

\section{REFERENCES}

Abu-Mostafa, Y. S., Magdon-Ismail, M., \& Lin, H. T. (2012). Learning from data (Vol. 4). New York, NY: AMLBook.com.

Allen, F., Carletti, E., \& Marquez, R. (2015). Deposits and bank capital structure. Journal of Financial Economics, 118(3), 601619.

Altman, E. I. (1968). Financial ratios, discriminant analysis and the prediction of corporation bankruptcy. Journal of Finance, 23(4), 589-609.
Altman, E. I. (1984). A further empirical investigation of the bankruptcy cost question. Journal of Finance, 39(4), 10671089.

Altman, E. I. (1993). Corporate financial distress and bankruptcy: a complete guide to predicting and avoiding distress and profiting from bankruptcy ( $3^{\text {rd }}$ ed.). New York, NY: Wiley Financial.

Alvarez-Jimenez, A. (2014). The great recession and the new frontiers of international investment law: The economics 
of early warning models and the law of necessity. Journal of International Economic Law, 17(3), 517-550.

Angelini, P., Maresca, G., \& Russo, D. (1996). Systemic risk in the netting system. Journal of Banking \& Finance, 20(5), 853-868.

Ayuso, J., Perez, D., \& Saurina, J. (2004). Are capital buffers procyclical? Evidence from Spanish panel data. Journal of Financial Intermediation, 13(2), 249-264.

Babecky, J., Havrànek, T., Mateju, J., Rusnák, M., Smídková, K. \& Vasícek, B. (2003). Leading indicators of crisis incidence: Evidence from developed countries. Journal of International Money and Finance, 35, 1-19.

Banco Central do Brasil. (1987). Plano contábil das instituições do sistema financeiro nacional. Retrieved from https://www.bcb. gov.br/htms/cosif/default.asp.

Banco Central do Brasil. (2017). Estatísticas de depósitos a prazo. Depósitos a prazo registrados na Câmara de Liquidação e Custódia, conforme a determinação da Resolução 3.272 e operacionalização disposta na Circular 3.282; balancetes gerais das instituições financeiras. Retrieved from http://www.bcb. gov.br/Fis/Estdeprazo/estprazo.asp.

Banco Central do Brasil. (2018). Relatório de estabilidade financeira. Retrieved from http://www.bcb.gov.br/htms/ estabilidade/ref/ref.asp?idpai=economia.

Baxter, N. (1967). Leverage, risk of ruin and the cost of capital. Journal of Finance, 22(3), 395-403.

Belém, V. C., \& Gartner, I. R. (2016). Empirical analysis of Brazilian banks' capital buffers during the period 2001-2011. Revista Contabilidade \& Finanças, 27(70), 113-124.

Bennett, R., \& Unal, H. (2014). Understanding the components of bank failure resolution costs [Working Paper]. United States Federal Deposit Insurance Corporation/Center for Financial Research. Retrieved from https://www.fdic.gov/bank/ analytical/cfr/2014/wp2014/2014-04.pdf.

Box, G. E. P., Jenkins, G. K., \& Reinsel, G. C. (2008). Time series analysis - forecasting and control ( $4^{\text {th }}$ ed.). Upper Saddle River, NJ: Prentice Hall.

Bris, A., Welch, I., \& Zhu, N. (2006). The cost of bankruptcy: Chapter 7 liquidation vs. chapter 11 reorganization. The Journal of Finance, 61(3), 1253-1303.

Bulow, J. I., \& Shoven, J. B. (1978). The bankruptcy decision. Bell Journal of Economics, 2(9), 437-456.

Comissão de Valores Mobiliários. (2002). CVM Instruction 361, of March $5^{\text {th }}$ of 2002. Describes the procedure applicable to public offers of shares in open companies, the recording of public offers of shares to cancel the recording of open companies, due to an increase in the controlling shareholder's share, alienation of control of an open company, for the acquisition of control of an open company when it involves an exchange for securities, and exchange for securities. Retrieved from http://www.cvm. gov.br/export/sites/cvm/legislacao/instrucoes/anexos/300/ inst361consolidsemmarcas.pdf

Conselho Administrativo de Recursos Fiscais. (2017). Imposto sobre a renda de pessoa jurídica - IRPJ. Retrieved from https://static.poder360.com.br/2017/08/ decisaoitauunibanco.pdf
Cox, D. R. (1972). Regression models and life-tables. Journal of the Royal Statistical Society, Series B (Methodological), 34(2), 187-220.

Dermine, J. (2010). Avaliação de bancos \& gestão baseada no valor. São Paulo, SP: Atlas.

Diamond, D. W., \& Rajan, R. G. (2000). A theory of bank capital. The Journal of Finance, 55(6), 2431-2465.

Donaldson, T., \& Preston, L. (1995). The stakeholder theory of the corporation: concepts, evidence, and implications. Academy of Management Review, 20(1), 65-91.

Financial Stability Board. (2014). Key attributes of effective resolution regimes for financial institutions. Retrieved from http://www.fsb.org/what-we-do/policy-development/ effective-resolution-regimes-and-policies/key-attributes-ofeffective-resolution-regimes-for-financial-institutions/.

Fisher, T., \& Martel, J. (2009). An empirical analysis of the firm's reorganization decision. Finance, 30(1), 121-149.

Frank, M. Z. \& Goyal, V. K. (2009). Capital structure decisions: Which factor are reliably important? Financial Management, 38(1), 1-37.

Gartner, I. R. (2015). Multi-attribute utility model based on the maximum entropy principle applied in the evaluation of the financial performance Brazilian banks. In P. Guarnieri (Ed.). Decision models in engineering and management (pp. 29-55). Basel: Springer.

Gilson, S., John, K., \& Lang, L. (1990). Troubled debt restructuring: an empirical study of private reorganization of firms in default. Journal of Financial Economics, 2(27), 315353.

Hankir, Y., Rauch, C., \& Umber, M. P. (2011). Bank M\&A: A market power story? Journal of Banking and Finance, 35(9), 2341-2354.

Hardy, D. C. (2013). Bank resolution costs, depositor preference, and encumbrance [Working Paper]. International Monetary Fund. Retrieved from https://papers.ssrn.com/sol3/papers. cfm?abstract_id=2307415\#\#.

Hill, C. W. L., \& Jones, T. M. (1992). Stakeholders-agency theory. Journal of Management Studies, 29(2), 131-154.

Ingersoll, J. E., Jr. (1987). Theory of financial decision making. Totowa, NJ: Rowman \& Littlefield.

Itaú Unibanco Banco Múltiplo S.A. (2008). Relatório anual de sustentabilidade. Retrieved from https://www. itau.com.br/_arquivosestaticos/RI/pdf/pt/RA_2008_ PT.pdf?title=Relat\%C3\%B3rio\%20Anual\%20-\%202008.

Itaúsa - Investimentos Itaú S.A e Unibanco Holdings S.A. (2008). Fato relevante: a associação entre Itaú e Unibanco. Retrieved from https://www.itau.com.br/relacoes-com-investidores/ comunicados-e-eventos/comunicados-anteriores-a-2008.

James, C. (1991). The losses realized in bank failures. Journal of Finance, 46(4), 1223-1242.

Janot, M. M. (2001). Modelos de previsão de insolvência bancária no Brasil [Texts for Discussion]. Banco Central do Brasil. Retrieved from https://www.bcb.gov.br/pec/wps/port/wps13. pdf 
Jensen, C, \& Meckling, H. (1976). Theory of the firm: managerial behavior, agency costs and ownership structure. Journal of Financial Economic, 4(3), 1-77.

Kaufman, G. G. (1994). Bank contagion: A review of the theory and evidence. Journal of Financial Services Research, 8(2), 123-150.

Koch, T. W., \& MacDonald, S. S. (2000). Bank management (4a. ed.). San Diego, CA: Harcourt Brace \& Co.

Kraus, A., \& Litzenberger, R. 1973. A state-preference model of optimal financial leverage. The Journal of Finance, 28(4), 911922.

Law n. 9,532, of December $10^{\text {th }}$ of 1997. (1997, December $11^{\text {th }}$ ). Altera a legislação tributária federal e dá outras providências. Alters the federal tax legislation and makes other provisions. Retrieved from http://www.planalto.gov.br/ccivil_03/leis/ L9532.htm.

Luamoto, R. I. (2009). Modelando o prêmio pelo risco cambial no Brasil através de modelos GARCH-M: o mercado forward reflete a visão dos economistas? (Master's Dissertation). Escola de Economia da Fundação Getúlio Vargas, São Paulo. Retrieved from https://bibliotecadigital.fgv.br/dspace/ bitstream/handle/10438/2643/Rog\%C3\%83\%C2\%A9rio\%20 Iwao\%20Iuamoto.pdf.

Mason, J. R. (2005). A real options approach to bankruptcy costs: evidence from failed commercial banks during the 1990s. The Journal of Business, 78(4), 1523-1554.

Modigliani, F., \& Miller, M. H. (1958). The cost of capital, corporate finance and the theory of investment. American Economic Review, 48(3), 261-297.

Modigliani, F., \& Miller, M. H. (1963). Corporate income taxes and the cost of capital: a correction. American Economic Review, 53(3), 433-442.

Nanda, S., \& Pendharkar, P. (2001). Linear models for minimizing misclassification costs in bankruptcy prediction. International Journal of Intelligent Systems in Accounting, Finance and Management, 10(3), 155-168.

Rasiah, D., \& Kim, P. K. K. (2011). A theoretical review on the use of the static trade-off theory, the pecking order theory and agency cost theory of capital structure. International Research
Journal of Finance and Economic, 63, 150-159.

Ravi, V., \& Pramodh, C. (2008). Threshold accepting trained principal component neural network and feature subset selection: Application to bankruptcy prediction in banks. Applied Soft Computing, 8(4), 1539-1548.

Sercu, P. (1980). A generalization of the international asset pricing model. Revue de l'Association Française de Finance, 1(1), 91-135.

Sheng, A. (1990). The art of bank restructuring: Issues and techniques. Paper presented at EDI Senior Policy Seminar on Financial Systems and Development in Africa, Nairobi.

Solnik, B. (1983). International arbitrage pricing theory. Journal of Finance, 38(2), 449-457.

Trevisan Auditores e Consultores Ltda. (2003). Laudo de avaliação econômico-financeira do Unibanco e da Unibanco Holdings: 30 de junho de 2003. Retrieved from http://sistemas.cvm.gov.br/ dados/LaudEditOpa/RJ-2003-06670/20030911_LAUDO_DE_ AVALIACAO.PDF).

União de Bancos Brasileiros S.A. (2008a). Comunicado ao mercado. Retrieved from https://ww13.itau.com.br/PortalRI/UHtml/arq/ publicacao/207378/Release_3T08_pdf_revisada.pdf

União de Bancos Brasileiros S.A. (2008b). Demonstração financeira individual referente ao exercício findo em 30 de setembro. Retrieved from https:// www.itau.com.br/_arquivosestaticos/RI/pdf/pt/ ITR_UBB_0908_PT.pdf?title=Uni\%C3\%A3o $\% 20$ de $\% 20$ Bancos\%20Brasileiros\%20S.A.\%20-\%20 \%C2\%A0Demonstra\%C3\%A7\%C3\%B5es\%20 Financeiras\%20em $\% 2030 \% 20$ de $\% 20$ setembro\%20de $\% 20$ 2008\%20(PDF).

White, M. J. (1983). Bankruptcy costs and the new bankruptcy code. The Journal of Finance, 38(2), 477-488.

White, M. J. (1989). The Corporate bankruptcy decision. Journal of Economic Perspectives, 3(2), 129-151.

Yildiz, B., \& Akkoc, S. (2010). Bankruptcy prediction using neuro fuzzy: An application in Turkish banks. International Research Journal of Finance and Economics, 60(1), 114-126.

Zaghdoudi, T. (2013). Bank failure prediction with logistic regression. International Journal of Economics and Financial Issues, 3(2), 537-543. 